\title{
Halomonas ilicicola sp. nov., a moderately halophilic bacterium isolated from a saltern
}

\author{
Correspondence \\ Juan Soliveri \\ juan.soliveri@uah.es
}

\author{
María Arenas, ${ }^{1}$ Patricia I. Bañón, ${ }^{1}$ José L. Copa-Patiño, ${ }^{1}$ Cristina Sánchez- \\ Porro, ${ }^{2}$ Antonio Ventosa ${ }^{2}$ and Juan Soliveri ${ }^{1}$ \\ ${ }^{1}$ Departamento de Microbiología y Parasitología, Facultad de Farmacia, Universidad de Alcalá, \\ 28871 Alcalá de Henares, Madrid, Spain \\ ${ }^{2}$ Departamento de Microbiología y Parasitología, Facultad de Farmacia, Universidad de Sevilla, \\ 41012 Sevilla, Spain
}

The family Halomonadaceae (Franzmann et al., 1988) belongs to the class Gammaproteobacteria which, at the time of writing, comprises seven genera: Halomonas (Dobson \& Franzmann, 1996), Carnimonas (Garriga et al., 1998), Chromohalobacter (Ventosa et al., 1989), Cobetia (Arahal et al., 2002b), Halotalea (Ntougias et al., 2007), Modicisalibacter (Ben Ali Gam et al., 2007) and Zymobacter (Okamoto et al., 1993). All members described in this family so far are able to grow at salinities between $5-10 \%(\mathrm{w} / \mathrm{v})$ except Zymobacter palmae (Okamoto et al., 1993). The genus Halomonas was originally proposed with the sole species Halomonas elongata to accommodate a group of Gramnegative, rod-shaped and extremely halotolerant strains (Vreeland et al., 1980).Taxonomically, the genus Halomonas is very heterogeneous and, at the time of writing, includes 49 species (http:///www.bacterio.cict.fr/). It was established by Arahal et al. (2002a) that this genus is not monophyletic on the basis of $16 \mathrm{~S}$ and $23 \mathrm{~S}$ rRNA gene sequence analyses. These authors distinguished two phylogenetic groups comprising

Abbreviation: SEM, scanning electron microscopy.

The GenBank/EMBL/DDBJ accession number for the 16S rRNA gene sequence of strain $\mathrm{SP}^{\top}$ is EU218533.

Additional phylogenetic trees based on neighbour-joining and maximumlikelihood analysis of the $16 \mathrm{~S}$ rRNA gene sequences of strain SP8 ${ }^{\top}$ and closely related species are available with the online version of this paper. different species with similar sequence similarities. In addition, several species did not clearly fall into either of the two groups mentioned and did not form a group themselves. All members of the family Halomonadaceae are aerobes, although some species of the genus Halomonas have been shown to grow anaerobically with nitrate, nitrite or fumarate as an electron acceptor and with glucose on solid media in sealed jars (Mata et al., 2002). In this paper, the features of a new strain isolated from a saltern are described and it is shown to represent a novel species of the genus Halomonas.

The Bras del Port solar salterns are located on the eastern coast of Spain close to the city of Santa Pola (Alicante) $\left(38^{\circ} 11^{\prime} 29.22^{\prime \prime} \mathrm{N} 0^{\circ} 35^{\prime} 39.70^{\prime \prime} \mathrm{W}\right)$. Strain $\mathrm{SP}^{\mathrm{T}}$ was isolated during the characterization of the microbial diversity in samples taken from a pond containing saturated brine collected during the salt washing process to remove particles and also to replace magnesium brine clinging to the salt crystals. This strain was selected for further study on the basis of its distinctive morphological features compared with the other isolates. The isolation was performed at $37{ }^{\circ} \mathrm{C}$ using the dilution plating technique and a modification of medium no. 29 from the CECT (http://www.cect.org), containing (\%, w/v): yeast extract (0.3), peptone (0.5), $\mathrm{NaCl}(15.0)$ and agar (2.0) and adjusted to $\mathrm{pH}$ 7.4. Subculturing was performed on $10 \%$ MH medium that had the following composition $(\%, w / v)$ : 
$\mathrm{NaCl}$ (8.1), $\mathrm{MgCl}_{2}$ (0.7), $\mathrm{MgSO}_{4}$ (0.96), $\mathrm{CaCl}_{2}$ (0.036), $\mathrm{KCl}$ (0.2), $\mathrm{NaHCO}_{3}(0.006), \mathrm{NaBr}(0.0026)$, proteose peptone (Difco) (0.5), yeast extract (Difco) (1.0), glucose (0.1) and agar (1.5) (Ventosa et al., 1982).

The procedures followed for phenotypic characterization have been described previously by Ventosa et al. (1982), Mata et al. (2002) and Arahal et al. (2007). Cellular morphology was examined by phase-contrast microscopy (model Axiolab; Zeiss) and scanning electron microscopy (SEM) (model DSM950; Zeiss) after growth on $10 \% \mathrm{MH}$ medium at $37{ }^{\circ} \mathrm{C}$. SEM imaging was performed with cells grown on inclined glass coverslips embedded into culture medium in a Petri dish. Cells were fixed using $5 \%$ formaldehyde in $0.2 \mathrm{M}$ cacodylate buffer, $\mathrm{pH} 7.2$ for $1 \mathrm{~h}$, followed by two washings with the same buffer. Cells were dehydrated by washing four times with increasing gradients of ethyl alcohol ranging from $25 \%$ to $100 \%$ and twice with acetone for $10 \mathrm{~min}$. The samples were stored overnight in anhydrous acetone. Critical point-drying was then performed using liquid carbon dioxide rinse cycles to remove traces of ethanol and acetone. Samples were heated to 30$40{ }^{\circ} \mathrm{C}$ to remove any remaining moisture. Samples were then sputter-coated with gold-palladium. The Gram reaction was performed as described by Gerhardt et al. (1994).

Cells were short rod-shaped with rounded ends; no endospores were observed (Fig. 1). Strain $\mathrm{SP} 8^{\mathrm{T}}$ was able to grow on $\mathrm{MH}$ medium supplemented with 2 to $17.5 \%$ (w/v) total salts and in MH medium supplemented with 2 to $17.5 \% \mathrm{NaCl}(\mathrm{w} / \mathrm{v})$. Optimal growth was found on $\mathrm{MH}$ medium with $10 \%(\mathrm{w} / \mathrm{v}) \mathrm{NaCl}$. Thus this micro-organism can be considered as moderately halophilic (Ventosa et al., 1998). Other morphological, physiological and biochemical characteristics of the novel strain are shown in Table 1 or are given in the species description.

For the determination of the DNA G $+\mathrm{C}$ content of strain $\mathrm{SP}^{\mathrm{T}}$, the extraction and purification of genomic DNA

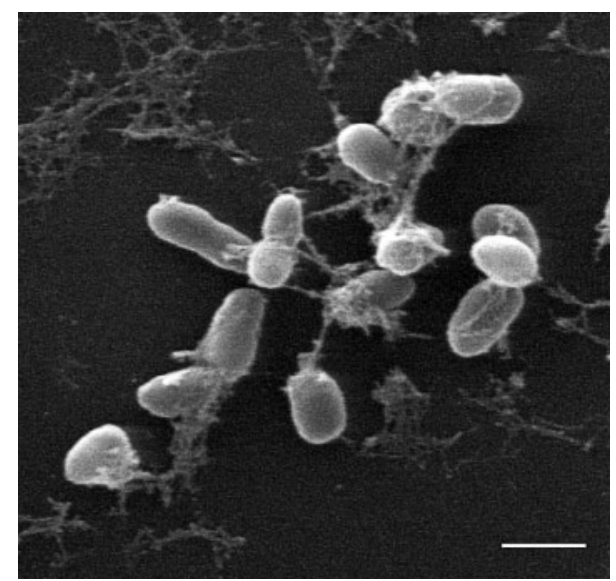

Fig. 1. SEM image of cells of strain $\mathrm{SP} 8^{\top}$. Cells were growth on $10 \% \mathrm{MH}$ medium at $37{ }^{\circ} \mathrm{C}$ for 3 days. Bar, $1 \mu \mathrm{m}$. was performed according to Marmur (1961). The G+C content was determined using the thermal denaturation method (Marmur \& Doty, 1962; Owen \& Hill, 1979). The phylogenetic position of strain $\mathrm{SP}^{\mathrm{T}}$ was determined by $16 \mathrm{~S}$ rRNA gene sequence analysis. The $16 \mathrm{~S}$ rRNA gene was amplified using oligonucleotide primers complementary to highly conserved regions of bacterial $16 \mathrm{~S}$ rRNA genes. The forward primer and the reverse primer were $27 \mathrm{~F}$ and 1492R (Reysenbach et al., 2000). PCR products were purified using an UltraClean PCR Clean-up kit (Mo Bio), according to the manufacturer's instructions. Purified PCR products were sequenced using the ABI Prism Big Dye Terminator cycle sequencing ready reaction kit and an Applied Biosystems 3130 Genetic Analyzer, using the protocols of the manufacturer (Applied Biosystems). Sequence assembly was performed using the CAP3 program (Huang \& Madan, 1999). The identification of phylogenetic neighbours and calculation of pairwise 16S rRNA gene sequence similarity were achieved using the EzTaxon server (http://www.eztaxon.org/; Chun et al., 2007). Subsequent sequence analysis was conducted using the ARB program package (Ludwig et al., 2004). Following the recommendations of Ludwig et al. (1998), alternative treeing methods (maximum-parsimony, neighbour-joining and maximum-likelihood) were used. The 16S rRNA gene sequence of strain $\mathrm{SP} 8^{\mathrm{T}}$ was a continuous stretch of $1423 \mathrm{bp}$ and was used for an initial BLAST search against the GenBank, EMBL and DDBJ databases. The 16S rRNA gene sequence of strain $\mathrm{SP}^{\mathrm{T}}$ and sequences of closely related strains were aligned and the phylogenetic trees showed that strain $\mathrm{SP}^{\mathrm{T}}$ clustered together with species of the genus Halomonas. The position of strain $\mathrm{SP}^{\mathrm{T}}$ in a tree constructed using maximum-parsimony is shown in Fig. 2. Similar topologies were obtained when other treeing methods were used (see Supplementary Fig. S1 in IJSEM Online). The sequence similarity matrix indicated that the closest relatives of strain $\mathrm{SP} 8^{\mathrm{T}}$ were Halomonas muralis LMG $20969^{\mathrm{T}}$ (96.0\% sequence similarity), Halomonas pantelleriensis $\mathrm{AAP}^{\mathrm{T}}(95.9 \%)$ and Halomonas campaniensis $5 \mathrm{AG}^{\mathrm{T}}(95.8 \%)$. Sequence similarities to all other species of the genus Halomonas included in the phylogenetic analyses were equal to or below $95.5 \%$. The DNA $\mathrm{G}+\mathrm{C}$ content of strain $\mathrm{SP}^{\mathrm{T}}$ was $66.9 \mathrm{~mol} \%$, similar to the values reported for the closely related species of Halomonas (Table 1).

Fatty acids were analysed by GC at the Belgian Coordinated Collections of Micro-organisms, Laboratory of Microbiology of Gent (BCCM/LMG), Gent, Belgium (Kämpfer \& Kroppenstedt, 1996; Miller, 1982). Cells were cultured on TSA medium supplemented with $10 \%(\mathrm{w} / \mathrm{v})$ $\mathrm{NaCl}$ for $48 \mathrm{~h}$ at $30{ }^{\circ} \mathrm{C}$. Strain $\mathrm{SP} 8^{\mathrm{T}}$ had a fatty acid profile similar to those described for the type strains of the closely related Halomonas species (Table 2). The predominant fatty acids are $\mathrm{C}_{18: 1} \omega 7 c$ and $\mathrm{C}_{16: 0 \text {. }}$

Based on these combined phenotypic and phylogenetic analyses, strain $\mathrm{SP}^{\mathrm{T}}$ is not closely affiliated with any recognized species. This organism is closely related to 


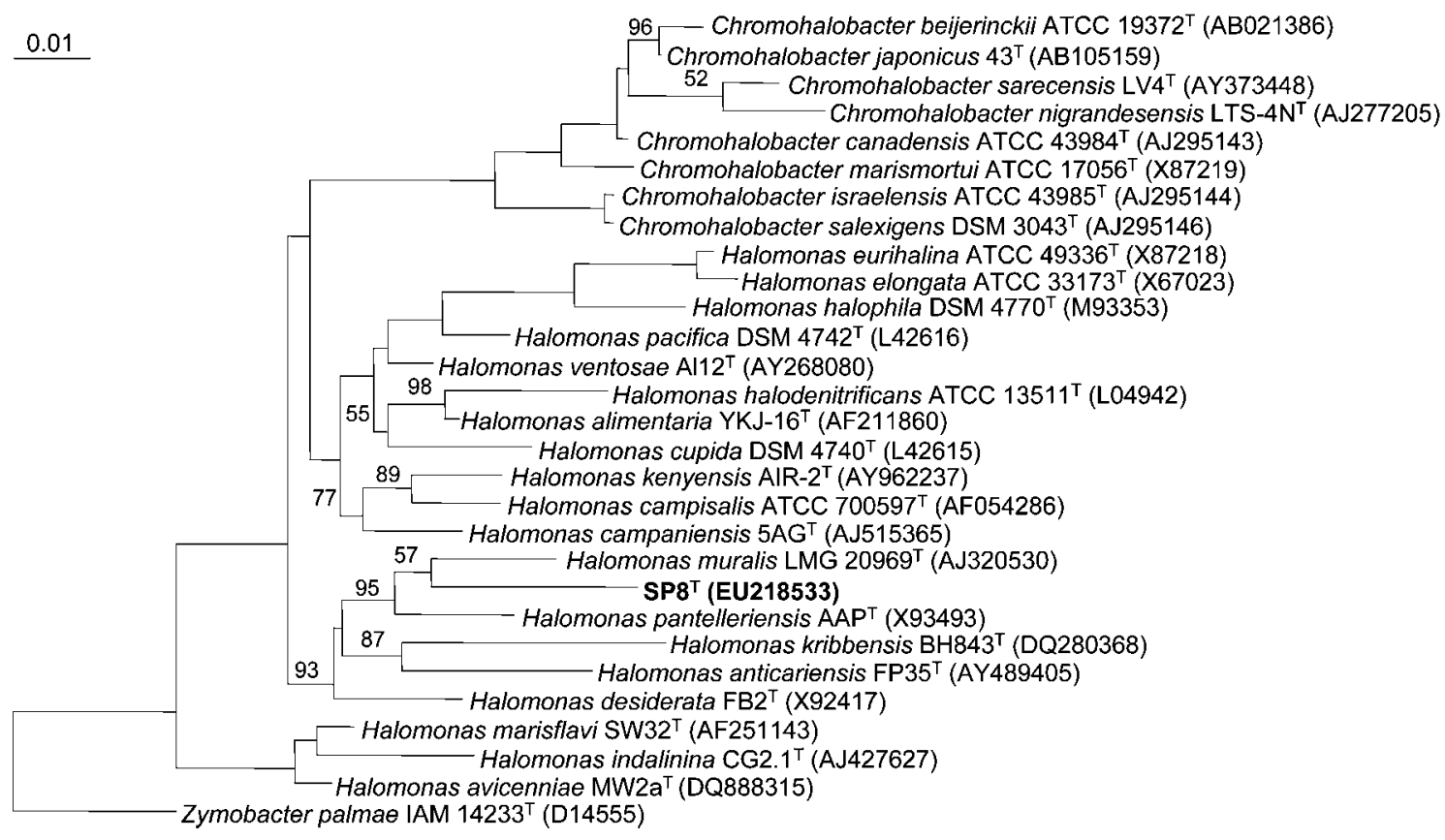

Fig. 2. Phylogenetic tree, based on maximum-parsimony, of $16 \mathrm{~S}$ rRNA gene sequences, showing the position of strain SP8 ${ }^{\top}$ and closely related species. Sequence accession numbers are shown in parentheses. Bootstrap values higher than $50 \%$ are indicated at branch-points. Zymobacter palmae $\mathrm{T} 109^{\top}$ was used as outgroup. Bar, $1 \%$ sequence divergence.

species of the genus Halomonas and we propose to include it as a novel species of this genus. The name Halomonas ilicicola sp. nov. is proposed for the novel species. Some features that enable Halomonas ilicicola sp. nov. to be differentiated from related species of the genus Halomonas are shown in Table 1.

\section{Description of Halomonas ilicicola sp. nov.}

Halomonas ilicicola (i.li.ci'co.la. L. n. ilici the Roman name of Elche, the city close to the solar salterns where the type strain was isolated; L. suff. - cola inhabitant, dweller; N.L. n. ilicicola inhabitant of Ilici).

Table 1. Characteristics that differentiate strain $\mathrm{SP}^{\top}$ and some related species of the genus Halomonas

Taxa: $1, \mathrm{SP}^{\mathrm{T}}$; 2, H. muralis (7 isolates); 3, H. pantelleriensis DSM $9661^{\mathrm{T}} ; 4$, H. elongata ATCC $33173^{\mathrm{T}}$. Data are from Arahal et al. (2002a); Heyrman et al. (2002); Martínez-Cánovas et al. (2004) and this study. +, Positive; -, negative; ND, not determined.

\begin{tabular}{|lcccc|}
\hline Characteristic & $\mathbf{1}$ & $\mathbf{2}$ & $\mathbf{3}$ & $\mathbf{4}$ \\
\hline Morphology & Short rods & Rods & Rods & Rods \\
Pigmentation & Pale orange & Colourless & Cream-pink & Colourless \\
Salt range (\%) & $2-17.5$ & $0-15$ & $1.2-15$ & $3.5-20$ \\
Temperature range $\left({ }^{\circ} \mathrm{C}\right)$ & $25-42$ & $10-35$ & $10-44$ & $15-45$ \\
pH range & $6.0-9.0$ & $5-10$ & $7.5-11$ & $5-9$ \\
Hydrolysis of gelatin & + & - & - & + \\
$\mathrm{H}_{2}$ S production & - & ND & + & - \\
Urease & - & - & + & + \\
Oxidase & - & + & + & + \\
Growth on: & & - & + & + \\
D-Fructose & + & $+/-$ & 65 & 60.5 \\
D-Mannose & - & 62.4 & 95.9 & 93.8 \\
DNA G+C content (mol\%) & 66.9 & 96.0 & & + \\
16S rRNA gene sequence similarity to & 100 & & & \\
strain SP8 ${ }^{\mathrm{T}}$ (\%) & & & & + \\
\hline
\end{tabular}


Table 2. Cellular fatty acid content (\%) of strain $\mathrm{SP}^{\top}, H$. muralis and $H$. elongata

Taxa: 1, strain SP8 ${ }^{\mathrm{T}} ; 2$, H. muralis $\mathrm{LMG} 20969^{\mathrm{T}} ; 3$, H. elongata ATCC $33173^{\mathrm{T}}$. Values $<0.5 \%$ are not shown; - , not detected.

\begin{tabular}{|lccc|}
\hline Fatty acid & $\mathbf{1}$ & $\mathbf{2}$ & $\mathbf{3}$ \\
\hline $\mathrm{C}_{10: 0}$ & 2.3 & 2.7 & 2.4 \\
$\mathrm{C}_{10: 0} 3-\mathrm{OH}$ & 3.8 & - & 3.1 \\
$\mathrm{C}_{12: 0}$ & 2.6 & 4.1 & 2.8 \\
$\mathrm{C}_{12: 0} 3-\mathrm{OH}$ & 8.2 & 8.8 & 7.7 \\
Summed feature $2^{*}$ & 1.1 & - & 0.9 \\
Summed feature $3^{*}$ & 8.9 & 18.8 & 5.8 \\
$\mathrm{C}_{16: 0}$ & 20.0 & 17.3 & 20.7 \\
$\mathrm{C}_{16: 0} 3-\mathrm{OH}$ & 0.9 & - & 0.8 \\
$\mathrm{C}_{17: 0}$ cyclo & 0.7 & - & 0.7 \\
$\mathrm{C}_{18: 1} \omega 7 c$ & 46.3 & 43.6 & 47.3 \\
$\mathrm{C}_{19: 0}$ cyclo $\omega 8 c$ & 3.4 & 2.0 & 6.1 \\
$\mathrm{C}_{19: 0} 10$ methyl & 1.0 & - & 0.7 \\
\hline
\end{tabular}

${ }^{\star}$ Summed features are groups of fatty acids which were not resolved chromatographically; summed feature 2 consists of $\mathrm{C}_{16: 1}$ iso I and/or iso- $\mathrm{C}_{14: 0} 3-\mathrm{OH}$; summed feature 3 consists of $\mathrm{C}_{16: 1} \omega 7 c$ and/or iso$\mathrm{C}_{15: 0} 2-\mathrm{OH}$.

Cells are short rods, $0.5-0.6 \times 0.8-1.1 \mu \mathrm{m}$, occur singly or in pairs, are motile, do not form endospores and stain Gram-negative. Colonies are circular, smooth, convex, pale orange, mucoid and $1.0-1.2 \mathrm{~mm}$ in diameter after 3 days incubation on $\mathrm{MH}$ medium at $37^{\circ} \mathrm{C}$. In liquid medium, grows producing a uniform turbidity. Exopolysaccharide is not produced. Poly- $\beta$-hydroxyalkanoates are not accumulated. Moderately halophilic, capable of growing in concentrations of between 2 and $17.5 \%(\mathrm{w} / \mathrm{v})$ salts. No growth occurs in the absence of salt. Optimal growth at $10 \%(\mathrm{w} / \mathrm{v})$ salts or $\mathrm{NaCl}$. The temperature range for growth is $25-42{ }^{\circ} \mathrm{C}$ with optimal growth at $37^{\circ} \mathrm{C}$. No growth detected at 15,20 or $45^{\circ} \mathrm{C}$. Growth occurs at $\mathrm{pH}$ 6.0-9.0 and is optimal at $\mathrm{pH}$ 6.5. Chemo-organotrophic. Metabolism is respiratory, with oxygen, nitrate or nitrite as terminal electron acceptor. Cells do not grow anaerobically in the presence of fumarate. Catalase is produced but not oxidase. D-Glucose is not fermented. Acid is produced from D-galactose, D-glucose, D-fucose, Dsorbitol, turanose and potassium 5-ketogluconate, but not from D-adonitol, L-arabinose, D-fructose, myo-inositol, Dlactose, maltose, D-mannose, melezitose, L-rhamnose, glycerol, D-mannitol, L-sorbose, trehalose or D-xylose. Gelatin and aesculin are hydrolysed, but not starch, casein, Tween 80 , DNA or tyrosine. Nitrate and nitrite are reduced (with gas formation). Grows on MacConkey and cetrimide agars supplemented with $10 \% \mathrm{NaCl}$. Methyl red test is positive. Indole and $\mathrm{H}_{2} \mathrm{~S}$ production are negative. The Voges-Proskauer test and tests for activities of urease and lysine-, ornithine- and arginine decarboxylases, ONPG and phenylalanine deaminase are negative. The following compounds can be used as sole carbon and energy sources: acetate, citrate, D-fructose, fumarate, D-galactose, gluconate, D-glucose, D-mannitol and propionate, but not aesculin, L-arabinose, cellobiose, ethanol, formate, lactose, D-mannitol, D-mannose, malonate, maltose, myo-inositol, D-ribose, starch, succinate, trehalose or D-xylose. L-Alanine can be used as sole carbon, nitrogen and energy sources, but not L-cysteine, L-histidine, L-lysine, L-methionine, Lserine or L-valine. Cells are sensitive to ( $\mu \mathrm{g}$ per disc) trimethoprim/sulfamethoxazole (1.25/23.75). Intermediate resistance to ( $\mu \mathrm{g}$ per disc): erythromycin (15), nalidixic acid (30) and rifampicin (5). Resistant ( $\mu \mathrm{g}$ per disc) to penicillin (10 U), vancomycin (30), chloramphenicol (30), streptomycin (10), bacitracin (10), cephalothin (30), novobiocin (30) neomycin (30), kanamycin (30) and tetracycline (30). The predominant fatty acids are $\mathrm{C}_{18: 1} \omega 07 c$ and $\mathrm{C}_{16: 0}$ (Table 2).

The type strain, $\mathrm{SP}^{\mathrm{T}}\left(=\right.$ CECT $7331^{\mathrm{T}}=$ CCM $7522^{\mathrm{T}}=$ DSM $19980^{\mathrm{T}}$ ), was isolated from a salty water sample from the solar salterns of Santa Pola (Alicante), located on the Mediterranean coast of Spain. The DNA G $+\mathrm{C}$ content of the type strain is $66.9 \mathrm{~mol} \%$ ( $T_{\mathrm{m}}$ method).

\section{Acknowledgements}

The authors are grateful to Alfonso Cuervo-Arango (Bras del Port S.A. salterns) for providing us with the samples. We thank Dr Pilar Rubio (Molecular Biology Unit, University of Alcala) for helping with the sequencing work. This study was supported by grants from the Ibercaja-University of Alcala (conv. 2006), the Spanish Ministerio de Educación y Ciencia (project BIO2006-006927) and from the Junta de Andalucía (project P06-CVI-01829).

\section{References}

Arahal, D. R., Ludwig, W., Schleifer, K. H. \& Ventosa, A. (2002a). Phylogeny of the family Halomonadaceae based on 23S and 16S rDNA sequence analyses. Int J Syst Evol Microbiol 52, 241-249.

Arahal, D. R., Castillo, A. M., Ludwig, W., Schleifer, K. H. \& Ventosa, A. (2002b). Proposal of Cobetia marina gen. nov., comb. nov., within the family Halomonadaceae, to include the species Halomonas marina. Syst Appl Microbiol 25, 207-211.

Arahal, D. R., Vreeland, R. H., Litchfield, C. D., Mormile, M. R., Tindall, B. J., Oren, A., Bejar, V., Quesada, E. \& Ventosa, A. (2007). Recommended minimal standards for describing new taxa of the family Halomonadaceae. Int J Syst Evol Microbiol 57, 24362446.

Ben Ali Gam, Z., Abdelkafi, S., Casalot, L., Tholozan, J. L., Oueslati, R. \& Labat, M. (2007). Modicisalibacter tunisiensis gen. nov., sp. nov., an aerobic, moderately halophilic bacterium isolated from an oilfield-water injection sample, and emended description of the family Halomonadaceae Franzmann et al. 1989 emend Dobson and Franzmann 1996 emend. Ntougias et al. 2007. Int J Syst Evol Microbiol 57, 2307-2313.

Chun, J., Lee, J.-H., Jung, Y., Kim, M., Kim, S., Kim, B. K. \& Lim, Y. W. (2007). EzTaxon: a web-based tool for the identification of prokaryotes based on $16 \mathrm{~S}$ ribosomal RNA gene sequences. Int J Syst Evol Microbiol 57, 2259-2261.

Dobson, S. J. \& Franzmann, P. D. (1996). Unification of the genera Deleya (Baumann et al. 1983), Halomonas (Vreeland et al. 1980), and Halovibrio (Fendrich 1988) and the species Paracoccus halodenitrifi- 
cans (Robinson and Gibbons 1952) in to a single genus, Halomonas, and placement of the genus Zymobacter in the family Halomonadaceae. Int J Syst Bacteriol 46, 550-558.

Franzmann, P. D., Wehmeyer, U. \& Stackebrandt, E. (1988). Halomonadaceae fam. nov., a new family of the class Proteobacteria to accommodate the genera Halomonas and Deleya. Syst Appl Microbiol 11, 16-19.

Garriga, M., Ehrmann, M. A., Arnau, J., Hugas, M. \& Vogel, R. F. (1998). Carnimonas nigrificans gen. nov., sp. nov., a bacterial causative agent for black spot formation on cured meat products. Int J Syst Bacteriol 48, 677-686.

Gerhardt, P., Murray, R. G. E., Wood, W. A. \& Krieg, N. R. (editors) (1994). Methods for General and Molecular Bacteriology. Washington, DC: American Society for Microbiology.

Heyrman, J., Balcaen, A., De Vos, P. \& Swings, J. (2002). Halomonas muralis sp. nov., isolated from microbial biofilms colonizing the walls and murals of the Saint-Catherine chapel (Castle Herberstein, Austria). Int J Syst Evol Microbiol 52, 2049-2054.

Huang, X. \& Madan, A. (1999). CAP3: A DNA sequence assembly program. Genome Res 9, 868-877.

Kämpfer, P. \& Kroppenstedt, R. M. (1996). Numerical analysis of fatty acid patterns of coryneform bacteria and related taxa. Can J Microbiol 42, 989-1005.

Ludwig, W., Strunk, O., Klugbauer, S., Klugbauer, N., Weizenernegger, M., Neumaier, J., Bachleitner, M. \& Schleifer, K.-H. (1998). Bacterial phylogeny based on comparative sequence analysis. Electrophoresis 19, 554-568.

Ludwig, W., Strunk, O., Westram, R., Richter, L., Meier, H., Yadhukumar, Buchner, A., Lai, T., Steppi, S. \& other authors (2004). ARB: a software environment for sequence data. Nucleic Acids Res 32, 1363-1371.

Marmur, J. (1961). A procedure for the isolation of deoxyribonucleic acid from microorganisms. J Mol Biol 3, 208-218.

Marmur, J. \& Doty, P. (1962). Determination of the base composition of deoxyribonucleic acid from its thermal denaturation temperature. J Mol Biol 5, 109-118.

Martínez-Cánovas, M. J., Quesada, E., Llamas, I. \& Béjar, V. (2004). Halomonas ventosae sp. nov., a moderately halophilic, denitrifying, exopolysaccharide-producing bacterium. Int J Syst Evol Microbiol 54, 733-737.

Mata, J. A., Martínez-Canovas, M. J., Quesada, E. \& Béjar, V. (2002). A detailed phenotypic characterisation of the type strains of Halomonas species. Syst Appl Microbiol 25, 360-375.

Miller, L. T. (1982). Single derivation method for routine analysis of bacterial whole-cell fatty acid methyl esters, including hydroxyl acids. J Clin Microbiol 16, 584-586.

Ntougias, S., Zervakis, G. I. \& Fasseas, C. (2007). Halotalea alkalilenta gen. nov., sp. nov., a novel osmotolerant and alkalitolerant bacterium from alkaline olive mill wastes, and emended description of the family Halomonadaceae Franzmann et al. 1989, emend. Dobson and Franzmann 1996. Int J Syst Evol Microbiol 57, 19751983.

Okamoto, T., Taguchi, H., Nakamura, K., Ikenaga, H., Kuraishi, H. \& Yamasato, K. (1993). Zymobacter palmae gen. nov., sp. nov., a new ethanol-fermenting peritrichous bacterium isolated from palm sap. Arch Microbiol 160, 333-337.

Owen, R. J. \& Hill, L. R. (1979). The estimation of base compositions, base pairing and genome sizes of bacterial deoxyribonucleic acids. In Chemical Methods for Microbiologists, pp. 277-296. Edited by F. A. Skinner \& D. W. Lovelock. London: Academic Press.

Reysenbach, A. L., Longnecker, K. \& Kirshtein, J. (2000). Novel bacterial and archaeal lineages from an in situ growth chamber deployed at a mid-Atlantic ridge hydrothermal vent. Appl Environ Microbiol 66, 3798-3806.

Ventosa, A., Quesada, E., Rodríguez-Valera, F., Ruiz-Berraquero, F. \& Ramos-Cormenzana, A. (1982). Numerical taxonomy of moderately halophilic Gram-negative rods. J Gen Microbiol 128, 1959 1968.

Ventosa, A., Gutiérrez, M. A., García, M. T. \& Ruiz-Berraquero, F. (1989). Classification of "Chromobacterium marismortui" in a new genus, Chromohalobacter gen. nov., as Chromohalobacter marismortui comb. nov., nom. rev. Int J Syst Bacteriol 39, 382-386.

Ventosa, A., Nieto, J. J. \& Oren, A. (1998). Biology of moderately halophilic aerobic bacteria. Microbiol Mol Biol Rev 62, 504-544.

Vreeland, R. H., Litchfield, C. D., Martin, E. L. \& Elliot, E. (1980). Halomonas elongata, a new genus and species of extremely salttolerant bacteria. Int J Syst Bacteriol 30, 485-495. 